\title{
Perbandingan Metode International Roughness Index Dengan Pavement Condition Index Untuk Penentuan Kondisi Jalan Nasional di Kota Wamena (Studi Kasus : Ruas Jalan Wamena - Habema)
}

\author{
Muhamad Agung Rahman', Herdianto Arifin², Bertho Orbain Sowolino ${ }^{3}$ \\ Balai Besar Pelaksanaan Jalan Nasional DKI Jakarta - Jawa Barat \\ Kementerian Pekerjaan Umum dan Perumahan Rakyat ${ }^{1}$ \\ Direktorat Preservasi Jalan dan Jembatan Wilayah II, Direktorat Jenderal Bina Marga, \\ Kementerian Pekerjaan Umum dan Perumahan Rakyat ${ }^{2,3}$ \\ Email: muhamad.rahman@pu.go.id ${ }^{1}$, herdi.arief.ha@gmail.com ${ }^{2}$, berthoosowolino@gmail.com ${ }^{3}$ \\ DOI: http://dx.doi.org/10.31869/rtj.v5i1.2702
}

\begin{abstract}
Abstrak: Pembangunan infrastruktur jalan merupakan suatu kebutuhan mutlak bagi pengembangan suatu wilayah agar tercapai kesinambungan dan pemerataan pembangunan pada setiap daerah serta membentuk struktur ruang dalam rangka mewujudkan sarana pembangunan nasional. Untuk membuka isolasi dan akses masyarakat terhadap perkembangan perekonomian di Kota Wamena, pemerintah melaksanakan pembangunan dan pemeliharaan jalan. Pemeliharaan jalan bertujuan untuk mempertahankan tingkat pelayanan sesuai dengan standar pelayanan minimum yang ditetapkan.
\end{abstract}

Penelitian ini dilakukan pada ruas Jalan Wamena-Habema sepanjang 35,100 kilometer. Penelitian ini bertujuan untuk membandingkan kondisi jalan hasil pengukuran metode IRI dengan metode $P C I$. Data yang digunakan berupa data IRI dan PCI semester 2 tahun 2020 yang diperoleh dari Sistem Pengelolaan Database Jalan Nasional (SiPDJN) Direktorat Jenderal Bina Marga Kementerian Pekerjaan Umum dan Perumahan Rakyat.

Hasil penelitian menunjukkan ada perbedaan kondisi jalan Wamena-Habema berdasarkan metode IRI dan metode PCI. Pada metode IRI 61,8\% kondisi baik, 32,2\% kondisi sedang. Kondisi rusak ringan dan rusak berat 4,0\% dan 2,0\%. Sedangkan pada metode $P C I 49,6 \%$ kondisi baik, 9,7\% kondisi sedang. Kondisi jelek dan parah 40,5\% dan 0,3\%. Dengan dilakukan penelitian kondisi jalan menggunakan metode IRI dan PCI pada ruas Jalan Wamena-Habema dapat memberikan deskripsi atau gambaran tentang data kondisi jalan eksisting. Data kondisi jalan dapat digunakan sebagai database untuk perencanaan dan pelaksanaan pemeliharaan jalan. Keywords : International Roughness Index, Pavement Condition Index, pemeliharaan jalan, kondisi jalan, jaringan jalan.

\section{PENDAHULUAN}

Menurut Undang-Undang Nomor 38 Tahun 2004, Jalan merupakan bagian prasarana transportasi yang mempunyai peran penting dalam bidang ekonomi, sosial budaya, lingkungan hidup, politik, pertahanan dan keamanan, serta dipergunakan untuk sebesar-besar kemakmuran rakyat. Selain itu, jalan berperan penting mendukung distribusi barang dan jasa untuk menunjang laju pertumbuhan ekonomi seiring dengan meningkatnya aksesibilitas dan mobilitas wilayah dalam mendukung pertumbuhan ekonomi dan kesejahteraan masyarakat.

Ruas Jalan Wamena - Habema yang menghubungkan antara Distrik Wamena dan Distrik Habema di Kabupaten Jayawijaya sepanjang 35,100 kilometer merupakan jalan nasional. Kewenangan penyelengaraan jalan nasional dilaksanakan oleh Pemerintah melalui Kementerian Pekerjaan Umum dan Perumahan Rakyat. Salah satu penyelenggaraan jalan adalah memprioritaskan pemeliharaan, perawatan dan pemeriksaan jalan secara berkala untuk mempertahankan tingkat pelayanan jalan sesuai dengan standar pelayanan minimal yang ditetapkan sebagaimana disebutkan dalam Undang-Undang No. 38 Tahun 2004 tentang Jalan. Sedangkan berdasarkan Peraturan Pemerintah Nomor 34 Tahun 2006 pasal 97 disebutkan bahwa penyelenggara jalan mempunyai kewajiban 
dan tangggung jawab untuk memelihara jalan sesuai dengan kewenangannya dimana pemeliharaan jalan merupakan prioritas tertinggi dari semua jenis penanganan jalan.

Survei pengumpulan data kondisi jaringan jalan perlu dilakukan secara periodik setiap tahun. Data kondisi jalan dapat dijadikan acuan untuk memonitor dan mengukur kondisi eksisting, membantu proses pengambilan keputusan strategis dalam manajemen jaringan jalan, dan membuat prakiraan kondisi yang akan datang. Selain itu, data kondisi jalan menjadi data utama dalam perencanaan umum jaringan jalan, pemrograman dan penganggaran, memonitor kinerja jaringan jalan, pengelolaan pengadaan kontrak pekerjaan pemeliharaan. Pengumpulan data kondisi jaringan jalan dapat dilakukan diantaranya dengan pengukuran menggunakan metode International Roughness Index (IRI) dan metode Pavement Condition Index (PCI). Nilai IRI diperoleh dengan survey menggunakan mobil dan alat NASSRA Roughmeter, mengunakan alat roaddroid, dan menggunakan alat profilometer kelas III tipe responsif yang menggunakan accelerometer. Sedangkan nilai $P C I$ diperoleh dengan melakukan survei lapangan secara visual.

Penelitian ini dilakukan untuk mengkaji kondisi perkerasan jalan pada ruas Jalan Wamena - Habema di Distrik Wamena dengan cara membandingkan kondisi jalan berdasarkan nilai International Roughness Index (IRI) dan nilai Pavement Condition Index (PCI) sehingga diperoleh usulan penanganan jalan yang dapat digunakan sebagai masukan untuk penyelenggara jalan dalam pemeliharaan jalan.

\section{TINJAUAN PUSTAKA \\ Penilaian Kondisi Jalan}

Penilaian terhadap kondisi perkerasan jalan merupakan aspek penting untuk menentukan kegiatan pemeliharaan dan perbaikan jalan (Setyawan dkk, 2016). Nilai kondisi jalan dapat dijadikan acuan untuk menentukan jenis program yang harus dilakukan. Penilian kondisi jalan pada penelitian ini menggunakan metode IRI dan PCI.

\section{Pemeliharaan Jalan}

Pemeliharaan Jalan merupakan kegiatan penanganan jalan berupa pencegahan, perawatan dan perbaikan yang diperlukan untuk mempertahankan kondisi jalan agar tetap berfungsi secara optimal melayani lalu lintas sehingga umur rencana yang ditetapkan dapat tercapai (Kementerian PUPR, 2016).

Pemeliharaan jalan meliputi pemeliharaan rutin, pemeliharaan berkala, dan rehabilitasi. Tabel 1 menunjukkan jenis penanganan pemeliharaan jalan beserta deskripsinya.

Tabel 1 Jenis Kegiatan Penanganan Pemeliharaan Jalan

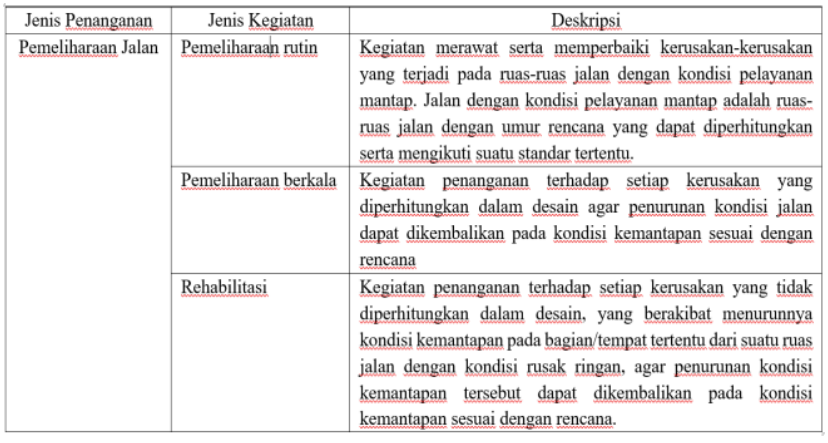

Sumber : PP No.34 Tahun 2006

\section{International Roughness Index (IRI)}

International Roughness Index (IRI) adalah index internasional yang menunjukkan besaran ketidakrataan permukaan jalan dalam satuan $\mathrm{m} / \mathrm{km}$ (Ditjen Bina Marga, 2010). Sedangkan menurut Sukirman (1999), IRI adalah parameter ketidakrataan yang dihitung dari jumlah kumulatif naik atau turunnya permukaan arah profil memanjang dibagi dengan jarak/panjang permukaan yang diukur.

Mengacu kepada Pedoman Survei Pengumpulan Data Kondisi Jaringan Jalan, Survei IRI dilaksanakan sebanyak 2 (dua) kali dalam setahun. Pelaksanan survei ini bermaksud untuk:

1. Memberikan gambaran umum kondisi jaringan jalan;

2. Mengembangkan model penurunan kondisi perkerasan; 
3. Memberikan masukan dalam optimasi pemeliharaan dan rehabilitasi jaringan jalan

4. Memberikan masukan untuk pemodelan dalam mengevaluasi efektifitas standar perencanaan perkerasan dan kebijakan pemeliharaan, dan menilai bagian biaya penyelenggaraan jalan dalam menunjang angkutan barang dan jasa.

Terdapat beberapa alat yang dapat digunakan untuk mendapatkan nilai IRI, antara lain dengan menggunakan alat NAASRA Roughmeter, menggunakan alaat Roaddroid, dan menggunakan alat Profilometer Kelas III Tipe responsif yang menggunakan accelerometer.

Klasifikasi kondisi jalan berdasarkan nilai IRI dibagi menjadi 4 kondisi, yaitu kondisi baik, kondisi sedang, kondisi rusak ringan, dan kondisi rusak berat seperti yang ditunjukkan pada Tabel 2.

Tabel 2 Hubungan Nilai IRI dengan Kondisi Jalan

\begin{tabular}{|c|c|}
\hline Nilai $I R I$ & Kondisi \\
\hline$\leq 4$ & Baik \\
\hline $4<I R I \leq 8$ & Sedang \\
\hline $8<I R I \leq 12$ & Rusak ringan \\
\hline$>12$ & Rusak berat \\
\hline
\end{tabular}

Sumber : Kementerian PU (2011)

Tabel 2. Jenis Penanganan Berdasarkan Kondisi Jalan

\begin{tabular}{|l|c|c|c|c|}
\hline \multicolumn{1}{|c|}{ Nilai IRI } & $\leq 4$ & $4,1-8,0$ & $8,1-12,0$ & $>12$ \\
\hline Kondisi Jalan & Baik & Sedang & Rusak Ringan & Rusak Berat \\
\hline $\begin{array}{l}\text { Jenis } \\
\text { Penanganan }\end{array}$ & $\begin{array}{c}\text { Pemeliharaan } \\
\text { rutin }\end{array}$ & $\begin{array}{c}\text { Pemeliharaan } \\
\text { rutin }\end{array}$ & $\begin{array}{c}\text { Pemeliharaan } \\
\text { berkala }\end{array}$ & $\begin{array}{c}\text { Peningkatan/ } \\
\text { rekonstruksi }\end{array}$ \\
\hline
\end{tabular}

\section{Pavement Condition Index (PCI)}

Pavement Condition Index (PCI) /

Indeks Kondisi Perkerasan (IKP) adalah suatu indeks numerik yang digunakan untuk menyatakan kondisi perkerasan jalan, berdasarkan suatu pengamatan visual terhadap jenis, tingkat keparahan dan sebaran kerusakan jalan (Kementerian PUPR, 2021). Sedangkan menurut Pedoman Penentuan Indeks Kondisi Perkerasan, Indeks Kondisi Perkerasan (IKP) adalah indikator kuantitatif (numerik) kondisi perkerasan yang mempunyai rentang nilai mulai dari 0 sampai dengan 100, dengan nilai 0 menyatakan kondisi perkerasan paling jelek yang mungkin terjadi dan nilai 100 menyatakan kondisi perkerasan terbaik yang mungkin dicapai, seperti yang diilustrasikan pada gambar 1 .

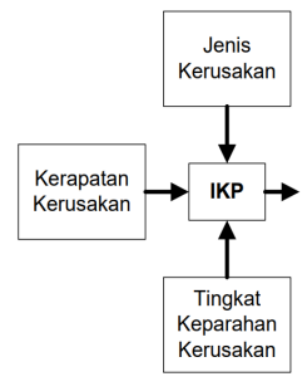

a. Prinsip penentuan IKP

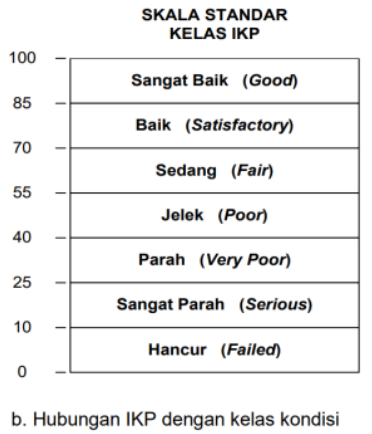

b. Hubungan IKP dengan kelas kondisi
Gambar 1 Skala kelas indeks kondisi perkerasan : a. Prinsip penentuan IKP; $b$.

Hubungan IKP dengan kelas kondisi

Sebagai indikator numerik kondisi perkerasan, IKP menunjukan tingkat kondisi permukaan perkerasan. IKP menunjukan ukuran kondisi perkerasan pada saat disurvei, berdasarkan kerusakan yang terpantau pada permukaan perkerasan, yang juga menunjukan kepaduan struktural dan kondisi fungsional perkerasan (ketidakrataan dan kekesatan). IKP tidak dapat mengukur kapasitas struktural perkerasan, juga tidak dapat menunjukkan ukuran panjang langsung kekesatan atau ketidakrataan. IKP merupakan dasar yang obyektif dan rasional untuk menentukan program pemeliharaan dan perbaikan yang diperlukan serta prioritas penanganan. Contoh penggunaan IKP untuk menentukan jenis penanganan terlihat pada Tabel 3

Tabel 3 Hubungan Nilai IKP dengan Jenis Penanganan

\begin{tabular}{|c|l|}
\hline Nilai IKP & \multicolumn{1}{|c|}{ Jenis Penanganan } \\
\hline$\geq 85$ & Pemeliharaan rutin \\
\hline $70-85$ & Pemeliharaan berkala \\
\hline $55-70$ & Peningkatan struktural \\
\hline$<55$ & Rekonstruksi/daur ulang. \\
\hline
\end{tabular}

\section{METODE PENELITIAN}

Penelitian ini dilakukan dengan melalui tahapan : (1) pengumpulan data berupa data IRI dan PCI (2) analisis kondisi jalan berdasarkan Nilai IRI dan Nilai PCI (3) melakukan perbandingan kondisi jalan 


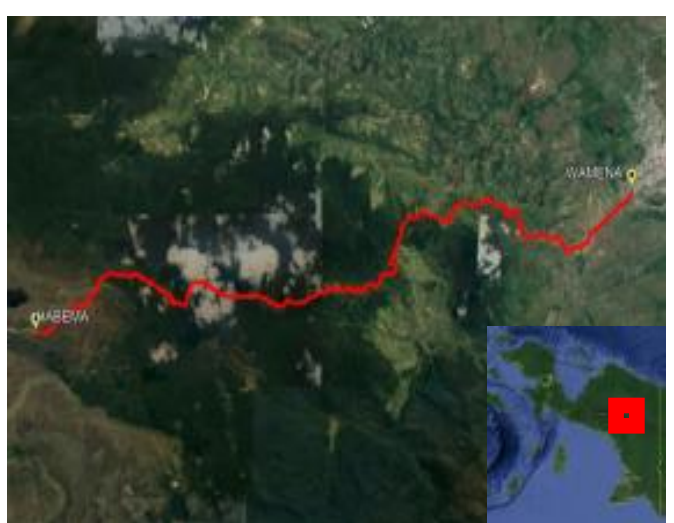

Gambar 2 Lokasi penelitian

Lokasi Penelitian ini dilaksanakan pada Ruas Jalan Wamena - Habema sepanjang 35,1 Km yang terletak di Distrik Wamena Kabupaten Jayawijaya Provinsi Papua. Gambar 2. menunjukan lokasi penelitian ini.

Data yang digunakan adalah data kondisi jalan Wamena-Habema hasil pengukuran IRI dan pengukuran PCI semester 2 Tahun 2020. Data diperoleh dari Sistem Pengelolaan Database Jalan Nasional (SiPDJN) Direktorat Jenderal Bina Marga Kementerian Pekerjaan Umum dan Perumahan Rakyat.

\section{HASIL DAN PEMBAHASAN \\ Kondisi Jalan Berdasarkan Nilai IRI}

Nilai IRI yang diperoleh dari hasil survei profil memanjang/keridakrataan IRI pada ruas jalan Wamena - Habema berada di rentang nilai $I R I 3,0$ s.d 25,0. Nilai IRI terendah yaitu 3,0 berada di lokasi STA $1+100$, STA $1+200$, STA $3+500$, STA $5+200$, STA $6+300$, dan STA $8+900$. Sedangkan nilai IRI tertinggi yaitu 25,0 berada di lokasi STA $18+200$. Adapun nilai IRI rata-rata ruas jalan Wamena - Habema sebesar 4,6 atau kondisi jalan sedang. Nilai IRI ruas jalan Wamena - Habema digambarkan dalam sebuah grafik seperti yang ditunjukkan oleh Gambar 3

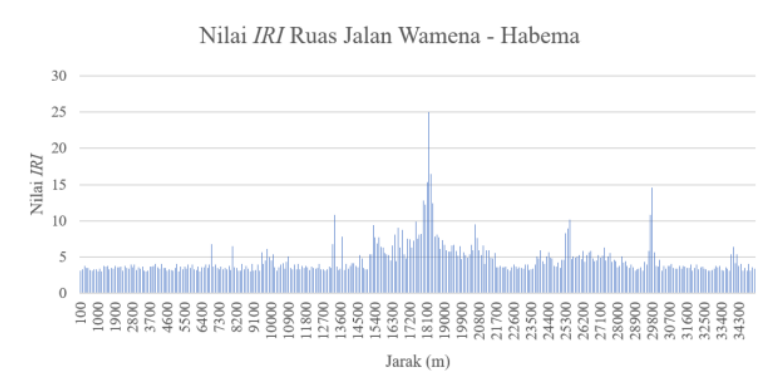

Gambar 3 Grafik Nilai IRI ruas Jalan Wamena - Habema

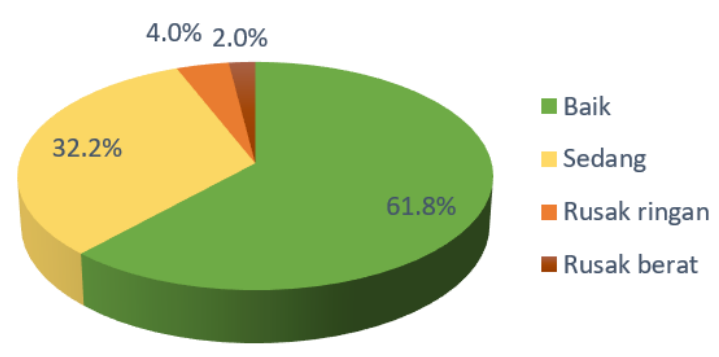

Gambar 4 Prosentase kondisi ruas Jalan Wamena - Habema berdasarkan nilai IRI

Gambar 4 menunjukkan prosentase kondisi jalan berdasarkan nilai IRI. Diketahui bahwa pada ruas jalan Wamena Habema kondisi jalan bervariasi, didominasi oleh kondisi jalan baik dan sedang. Kondisi jalan baik sebesar 61,8\% atau sepanjang $21,7 \mathrm{Km}$. Sedangkan kondisi jalan sedang sebesar 32,2\% atau sepanjang 11,3 Km. sementara itu, kondisi jalan rusak ringan dan rusak berat sebesar $4,0 \%(1,4 \mathrm{Km})$ dan 2,0\% (0,7 Km).

\section{Kondisi Jalan Berdasarkan Nilai PCI}

Nilai $P C I$ yang diperoleh dari hasil survei kondisi perkerasan jalan/PCI pada ruas jalan Wamena - Habema berada di rentang nilai PCI 39,5 s.d 79,0. Nilai PCI terendah yaitu 39,5 berada di lokasi STA $22+100$. Sedangkan nilai PCI tertinggi yaitu 79,0 berada di setengah panjang ruas jalan Wamena - Habema. Adapun nilai PCI ratarata ruas jalan Wamena - Habema sebesar 64,2 atau kondisi jalan sedang. Nilai $P C I$ ruas jalan Wamena - Habema digambarkan dalam sebuah grafik seperti yang ditunjukkan oleh Gambar 5. 
Nilai $P C I$ Ruas Jalan Wamena - Habema

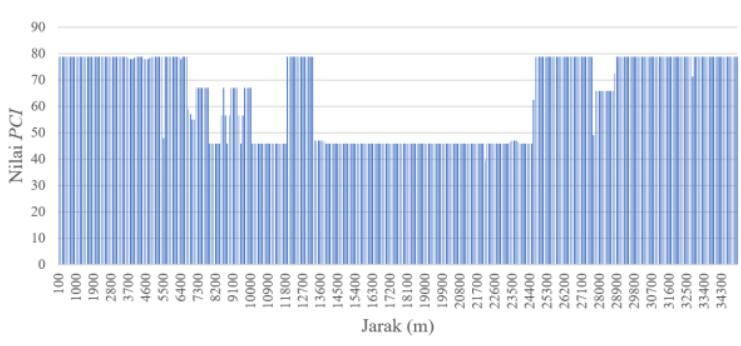

Gambar 5 Grafik Nilai $P C I$ ruas jalan Wamena - Habema

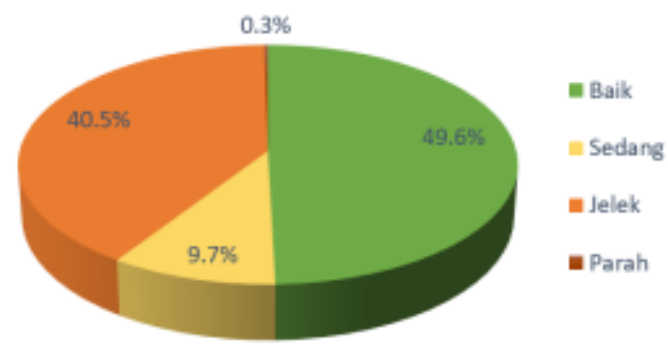

Gambar 6 Prosentase kondisi ruas Jalan Wamena - Habema berdasarkan nilai $P C I$

Gambar 6 menunjukkan prosentase kondisi jalan berdasarkan nilai $P C I$. Diketahui bahwa pada ruas jalan Wamena Habema kondisi jalan bervariasi, didominasi oleh kondisi jalan baik dan jelek. Kondisi jalan baik sebesar 49,6\% atau sepanjang 17,4 $\mathrm{Km}$ dan kondisi jalan sedang sebesar 9,7\% (3,4 Km). Sedangkan kondisi jalan jelek sepanjang 14,2 Km $(40,5 \%)$. Adapun kondisi jalan parah sebesar $0,3 \%(1 \mathrm{Km})$ berdasarkan nilai $P C I$.

\section{Perbandingan Kondisi Jalan}

Tabel 4 menunjukkan perbandingan kondisi jalan berdasarkan nilai IRI dan nilai $P C I$. Data yang diperoleh sebanyak 351 buah. Data yang menunjukkan hasil kondisi jalan yang sama sebanyak 157 data atau sebesar 44,73\%. Sedangkan data hasil kondisi jalan yang berbeda sebanyak 351 data $(55,27 \%)$. Akan tetapi, secara keseluruhan/rata-rata kondisi jalan yang diperoleh sama yakni kondisi jalan sedang untuk ruas Jalan Wamena - Habema.

Perbedaan data paling besar antara hasil nilai IRI dan PCI sebesar $19,7 \%$ yakni kondisi jalan sedang menurut nilai IRI, sedangkan menurut nilai $P C I$ kondisi jalan jelek. Rincian mengenai perbedaan data hasil pengukuran nilai IRI dan $P C I$ ditunjukkan pada Tabel 5.

Salah satu penyebab terjadinya perbedaan data dikarenakan perbedaan variabel yang diukur. survei IRI dilakukan untuk mendapatkan nilai ketidakrataan permukaan jalan pada arah memanjang di sepanjang ruas, sedangkan survei $P C I$ dilakukan untuk mendapatkan data kerusakan perkerasan jalan baik rigid maupun flexible pavement. 
Vol. 5 No.1 Januari 2022

http://jurnal.umsb.ac.id/index.php/RANGTEKNIKJOURNAL

Tabel 4 Perbandingan kondisi jalan berdasarkan nilai IRI dan nilai PCI

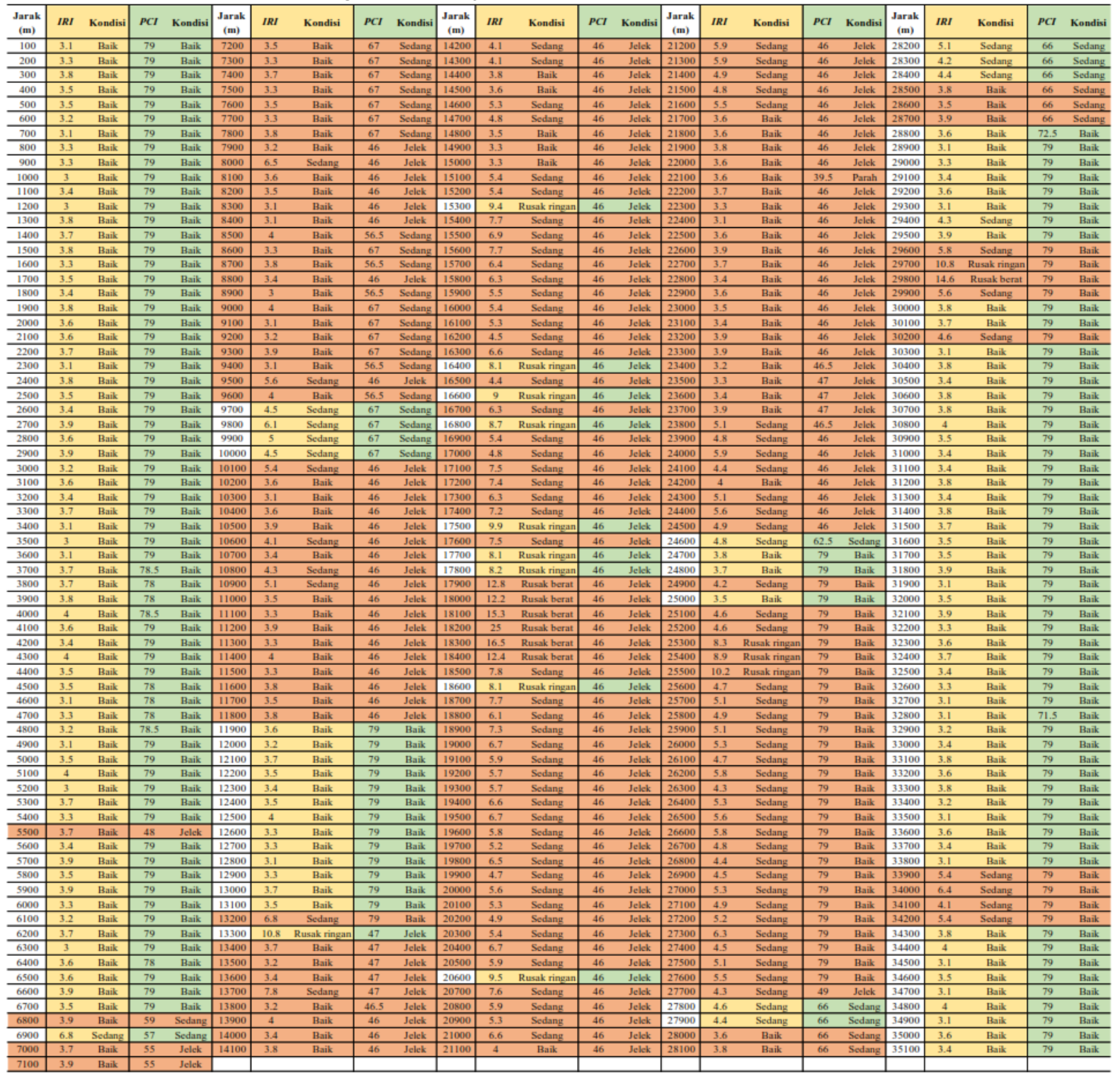

Tabel 5 Prosentase perbandingan kondisi jalan berdasarkan nilai $I R I$ dan nilai $P C I$

\begin{tabular}{|c|c|c|c|c|}
\hline \multicolumn{2}{|c|}{ Kondisi Jalan } & \multirow{2}{*}{ Jumlah Data } & \multirow{2}{*}{$\%$} & \multirow{2}{*}{ Keterangan } \\
\hline IRI & PCI & & & \\
\hline Baik & Baik & 136 & $38.7 \%$ & Hasil sama \\
\hline Sedang & Sedang & 11 & $3.1 \%$ & Hasil sama \\
\hline Rusak ringan & Jelek & 10 & $2.8 \%$ & Hasil sama \\
\hline Sedang & Jelek & 69 & $19.7 \%$ & Hasil berbeda \\
\hline Baik & Jelek & 57 & $16.2 \%$ & Hasil berbeda \\
\hline Sedang & Baik & 33 & $9.4 \%$ & Hasil berbeda \\
\hline Baik & Sedang & 23 & $6.6 \%$ & Hasil berbeda \\
\hline Rusak berat & Jelek & 6 & $1.7 \%$ & Hasil berbeda \\
\hline Rusak ringan & Baik & 4 & $1.1 \%$ & Hasil berbeda \\
\hline Rusak berat & Baik & 1 & $0.3 \%$ & Hasil berbeda \\
\hline \multirow[t]{2}{*}{ Baik } & Parah & 1 & $0.3 \%$ & Hasil berbeda \\
\hline & Jumlah & 351 & $100.0 \%$ & \\
\hline
\end{tabular}




\section{PENUTUP}

Berdasarkan pengukuran nilai $I R I$ pada ruas jalan Wamena - Habema diperoleh hasil kondisi jalan baik sebesar $61,8 \%$, kondisi jalan sedang, rusak ringan, dan rusak berat sebesar $32,2 \%, 4 \%$ dan $2 \%$. Sedangkan nilai $P C I$ diperoleh hasil kondisi jalan baik sebesar 49,6\%, kondisi jalan sedang sebesar 9,7\% serta kondisi jalan jelek dan parah sebesar $40,5 \%$ dan $0,3 \%$.

Meskipun terdapat perbedaan hasil kondisi jalan berdasarkan nilai IRI dan PCI, rata-rata kondisi jalan Wamena - Habema berada pada kondisi jalan sedang, sehingga penanganan pemeliharaan yang diperlukan didominasi oleh pemeliharaan rutin dan permeliharaan berkala.

\section{UCAPAN TERIMA KASIH}

Terima kasih disampaikan kepada Kementerian Pekerjaan Umum dan Perumahan Rakyat Republik Indonesia serta Direktorat Preservasi Jalan dan Jembatan Wilayah II Direktorat Jenderal Bina Marga Kementerian Pekerjaan Umum dan Perumahan Rakyat atas dukungan dan bantuan data dalam pelaksanaan penelitian ini.

\section{DAFTAR PUSTAKA}

Direktorat Jenderal Bina Marga. (2010). Pedoman Survei Kekasaran Permukaan Jalan dengan Alat NAASRA dan Visual. Jakarta: Departemen Pekerjaan Umum.

Kementerian Pekerjaan Umum dan Perumahan Rakyat. (2016). Pedoman Penentuan Indeks Kondisi Perkerasan (IKP).

Kementerian Pekerjaan Umum dan Perumahan Rakyat. (2021). Pedoman Survei Pengumpulan Data Kondisi Jaringan Jalan. Jakarta: Kementerian Pekerjaan Umum dan Perumahan Rakyat.

Direktorat Jenderal Bina Marga. (2011). Indonesia Integrated Road Management System (IIRMS) Panduan Survei Kondisi Jalan. Jakarta: Kementerian Pekerjaan Umum.

Direktorat Jenderal Bina Marga. (2016). Prosedur Pemeliharaan Jalan. Jakarta: Kementerian Pekerjaan Umum dan Perumahan Rakyat.

Pemerintah Indonesia. Undang-Undang Republik Indonesia Nomor 38 Tahun 2004 tentang Jalan (2004). Jakarta: Sekretariat Negara Republik Indonesia Pemerintah Indonesia. Peraturan Pemerintah
Nomor 34 Tahun 2006 Tentang Jalan (2006). Jakarta: Sekretariat Negara Republik Indonesia

Sukirman, S. (1999). Perkerasan Lentur Jalan Raya. Bandung: Nova.

Tho'atin, U., Setyawan, A., \& Suprapto, M. (2016). Penggunaan Metode International Roughness Index ( Iri ), Surface Distress Index ( $\mathrm{Sdi}$ ) Dan Pavement Condition Index ( Pci ) Untuk Penilaian Kondisi Jalan Di Kabupaten Wonogiri. Seminar Nasional Sains Dan Teknologi, (November), 1-9. 